
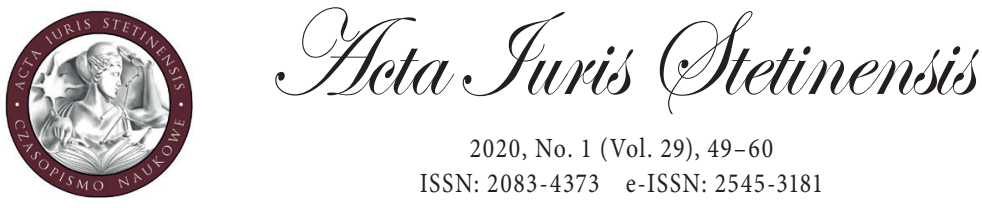

2020, No. 1 (Vol. 29), 49-60

ISSN: 2083-4373 e-ISSN: 2545-3181

DOI: $10.18276 /$ ais.2020.29-04

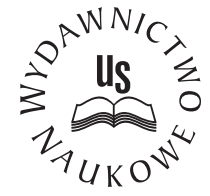

Paweł Kaźmierski

MA

Johannes Gutenberg University of Mainz, Germany

e-mail: pkazmier@students.uni-mainz.de

ORCID ID: 0000-0001-8287-3419.

\title{
Evolution of the suicides' right to funeral and burial in Canon Law and Polish Law
}

\begin{abstract}
For centuries, funeral law was not too favourable to suicides. Admittedly, at the dawn of Christianity this group of the deceased was not refused religious funeral celebrations or a burial, yet, the situation changed along with the Catholic religion gaining significance. At the beginning of the Middle Ages, suicides were deprived of the right to a religious funeral. Furthermore, in the $11^{\text {th }}$ century the ecclesiastical legislator forbade burial for suicides in "holy places." Until modern times, therefore, suicides were buried at a distance from graveyards. This in practice often indicated a burial insulting human dignity. The monopoly on religious funeral regulations only ended in Europe at the end of the $18^{\text {th }}$ century, when state authorities took an interest in funeral law. On Polish soil, the more enlightened regulations of the Partitioners were enforced in the $19^{\text {th }}$ century. In addition, the Act on burying the deceased passed in 1932 led to the necessary standardization of provisions of national funeral law, while the binding provisions of the Act on cemeteries of 1959 provided equality of rights for the deceased in the access to a place of burial at a cemetery. Finally, in the second half of the $20^{\text {th }}$ century, the ecclesiastical legislator introduced amendments to the Canon Law allowing (in certain instances) a Catholic funeral for a suicide. The liberalization of the Canon Law provisions, therefore, exemplifies wider transformations in the spirit of the conciliar aggiornamento.
\end{abstract}

Keywords: suicides, right to a burial, ecclesiastical funeral, Polish funeral law, Canon law 


\section{Introduction}

The aim of the paper is to present the evolution of funeral law provisions with regard to suicides that took place in Canon law and in Polish law in the last century. Due to the scarce number of municipal cemeteries and to historical cultural conditions in Polish lands until the $2^{\text {nd }}$ half of the $20^{\text {th }}$ century, Canon law regulations had had a significant impact on the legal situation of suicides in the scope of their right to a burial and right to a funeral. ${ }^{1,2}$ The religion-related diversification of the right of the suicide to a dignified place of burial in a denominational cemetery and unconditional deprivation of a Catholic funeral started to gradually give way to liberalisation of the canon funeral law provisions, especially under the influence of state legislation and under evolutionary changes in the Catholic Church itself. The latter was contributed to primarily by the development of science and by sessions of the Second Vatican Council.

For the purposes of the following reflections, the issue related to determining the meaning of the terms "a burial" and "a funeral" should be underlined. As aptly pointed out by Jan Gołąb, in Poland, there is no statutory definition of a funeral ${ }^{3}$. This situation is additionally complicated by different, often synonymous use of the above terms with reference to commonly binding legal provisions and the Canon law. ${ }^{4}$ Thus, "a burial" is understood herein as burying a human corpse or incinerated remains (human ashes) in any legally permitted form, whereas the term "a funeral" refers to the total of religious or secular rituals accompanying the burial. ${ }^{5}$ While it should be underlined in accordance with Anna Tunia that "the term "an ecclesiastical funeral " is not used in the Polish law," for the purposes of this paper, it will refer to the Catholic funeral ceremony pursuant to the Canon law provisions. ${ }^{6}$ Such

1 The number of municipal cemeteries even in the years 2014-2015 amounted to approx. 1,880 of the total number of over 10 thous. cemeteries functioning in Poland. See the Supreme Audit Office, Informacja o wynikach kontroli: Zarządzanie cmentarzami komunalnymi, Poznań 2016, p. 5.

2 According to the official declarations, 87.7 percent of all Poles are members of the Roman Catholic Church. See: Narodowy Spis Powszechny Ludności i Mieszkań. Struktura narodowo-etniczna, językowa i wyznaniowa ludności Polski, Warszawa 2015, p. 92.

3 Gołąb, J., Prawo do pogrzebu i jego wykonanie w prawie kanonicznym i prawie polskim, Rzeszów 2004, p. 203.

4 See: Walencik, D., Prawo do pogrzebu katolickiego a prawo do pochówku na cmentarzu wyznaniowym, in: Zubert, B.W. and Sztyk, W.J. (eds.), Munus sanctificandi: gaudium vel onus? Zadanie uświęcenia: radość czy ciężar?, Panewniki 2009, pp. 97-116.

5 In the case of a lack of a corpse, a so-called ritual funeral is possible, which is not performed with the burial. As specified by the canon law, see: Majer, P., Pogrzeb symboliczny po donacji zwłok na cele naukowe - aspekty prawnokanoniczne, "Annales Canonici" 2016, No. 12, pp. 91-114.

6 See: Tunia, A., Recepcja prawa wewnętrznego związków wyznaniowych w prawie polskim, Lublin 2015, p. 234. 
a terminological practice is analogical to the reference to the internal law of religious associations and in this case - the Catholic Church. ${ }^{7}$

\section{The historical background of funeral regulations in the Polish lands until 1795}

It would be difficult to consider the Catholic Church's position regarding suicide as uniform from the perspective of the past two thousand years. In the first centuries of existence, Christianity did not unequivocally condemn suicidal acts. ${ }^{8}$ This situation changed fundamentally in subsequent times, and is best exemplified by the explicit condemnation of suicide during the Synod in Arles in 452. Over time, the negative approach of Christian and particularly Catholic clerical hierarchy to suicide was manifested in the dimension of funeral regulations, the ban on conducting ecclesiastical funerals for suicides being stipulated as early as at the Synod in Braga in $563 .{ }^{9}$ At the end of the $11^{\text {th }}$ century, the restrictions increased, as the ecclesiastical legislator deprived suicides of the right to a burial in "consecrated ground." 10 Thus, the strict provisions of the canon law prevented suicides from having an ecclesiastical funeral and deprived them of the possibility of having a dignified burial, which was understood as burial in the Church itself and over time, also in the churchyard. ${ }^{11}$ At this point, it is worth underlining that in the Middle Ages, the religious element was dominant. This meant the lack of the possibility to conduct any funeral ceremony for the deceased. ${ }^{12}$ Corpses of suicides were buried in places commonly considered as undignified: outside the churchyard and often also as far from the Church as possible. A burial in the latter was disdainfully called a donkey's (Eselbegräbnis) or dog's (Hundbegräbnis) ${ }^{13}$ burial. In modern times, suicides began to be buried in denominational cemeteries; however, it took place in distant parts thereof - corners or places by the cemetery's wall, often the same place where

7 Ibidem.

8 Hołyst, B., Stosunek religii do samobójstwa, in: Hołtys, B., Suicydologia, Warszawa 2012, p. 112.

9 Insadowski, H., Kościelne prawo pogrzebowe, Włocławek 1930, p. 6.

10 Such restrictions were introduced during the Synod in Nimes, in 1096.

11 Sobczak, A., Poradnik cmentarny. Kościelne i cywilne normy prawne o cmentarzach i chowaniu zmarlych, wraz z orzecznictwem, Gniezno 2003, pp. 11-15.

12 For the first time secular funerals were organised in Poland only in the post-war period. See: Kubiak, A.E., Pogrzeby to nasze życie, Warszawa 2009, pp. 221-239.

13 See: Duma, P., Grób alienata. Pochówki dzieci nieochrzczonych, samobójców i skazańców w późnym średniowieczu i dobie wczesnonowożytnej, Kraków 2010, pp. 58-81. The author enumerates in the publication in detail all possible types of places in which suicides could be buried. 
unbaptised children were buried. ${ }^{14}$ In towns and cities in the South of Poland, until the early years of the $20^{\text {th }}$ century, there were still cases of burying suicides at the crossroads or in forest wastelands. ${ }^{15}$ At these times, there were even instances of drowning the corpses of suicides. ${ }^{16}$ The aforementioned funeral practices with regard to suicides were not as much a reminiscence of the Middle Ages' inclination to dispatching corpses of sinners far away from "holy places," but rather cultivating old folk rituals which regarded suicides with fear and manifested the faith in the possibility of their return in a form of ghouls. ${ }^{17}$

What is interesting, references to the old fear of the return of the dead can even be found in the contemporary culture of burial in Poland, especially in smaller local communities. ${ }^{18}$ It should be underlined that due to the denominational character of cemeteries in the period from the Middle Ages until the dawn of modern times, it is impossible to distinguish national law provisions that would regulate cemetery issues. Simultaneously, with regard to the contemporary sanitary reality, it was impossible to build private cemeteries in pre-partitioned Republic of Poland. ${ }^{19}$ Therefore, the practical monopoly of the canon law in the sphere of funeral regulations resulted not only from the principal position of the Catholic Church that governed the First Polish Republic until the end thereof. ${ }^{20}$ Still, pre-partitioned Poland was, nonetheless, positively enlightened, in comparison with other European states, in the scope of the lack of penalisation of a suicide in criminal law. Both, the land law, as well as the German law binding at that time in Polish cities and towns did not impose any criminal penalties for a suicidal act. ${ }^{21}$ This situation did not significantly change even in the later period of Polish lands during the Partitions. ${ }^{22}$

14 Ibidem, pp. 64-65.

15 Numerous examples of such local customs can be found in the ethnographic work of Adam Fischer. See: Fischer, A., Zwyczaje pogrzebowe ludu polskiego, Lwów 1921, pp. 354-361.

16 Bojko, J., Okruszyny z Gremboszowa, Lwów 1911, p. 108.

17 Fischer, op. cit., p. 361.

18 See: Kubiak, A.E., op. cit., pp. 323-343.

19 See: Kolbuszewski, J., Cmentarze, Wrocław 1996, p. 54.

20 Even the Governance Act (the Constitution of 3 May) enacted in 1791 included provisions calling the Catholic religion "national" or banning apostasy.

21 Wrzyszcz, A., Samobójstwo w prawie obowiązującym na ziemiach polskich do 1932 roku, in: Mozgawa, M. (ed.), Samobójstwo, Warszawa 2017, pp. 43-63.

22 For instance, Theresiana, penalising suicides and binding as of 1764 in the Habsburg Monarchy, was not introduced in the lands of the Austrian Partition, whereas, its "fundamental difference from the Polish law" was referred to. See: ibidem, pp. 48-49. 


\section{Unification of the district funeral law of 1932 and codification of the Canon law in the Code of Canon Law of 1917}

Independence in 1918 meant the necessity of dealing with the collision of the Partitioner's contradictory legal orders in the territory of reborn Poland. As aptly stated by Stanisław Płaza, legislation constituting the normative legacy of the partition legislation "was treated not as foreign law, but as Polish district law." 23 By nature, it was impossible, although initially considered, to restore the old law from the times of the First Polish Republic. ${ }^{24}$ Therefore, the laws of the Partitioners were maintained solely in order to preserve the principle of the continuity of law. ${ }^{25}$ Being aware of the temporary character of these regulations, the necessity to develop new uniform Polish regulations for the whole territory of the reborn Republic of Poland, was commonly accepted. ${ }^{26}$

In the period when Polish lands remained under partition, the role of the state in regulating sanitary issues related to the burial of corpses, commonly growing in Europe and initiated at the turn of the $18^{\text {th }}$ and $19^{\text {th }}$ centuries, constituted a significant funeral novum. Thus, the period of the monopoly of the internal law of religious associations in this regard ended. ${ }^{27}$ At this point, it is worth referring to the basic legal acts regulating funeral issues in the transitional period of binding district law. In the territory of the former Prussian partition, the pertinent regulations of the Kingdom of Prussia that were binding in the first years of the Second Polish Republic, in total, comprised 4 ministerial regulations: of 19 February 1823, 28 January 1830, 12 November 1835 and 20 January $1890 .{ }^{28}$ In Galicia, the provisions of the former Austria-Hungary Monarchy that were binding were pursuant to the court decree issued on 12 August 1788 on the joint burial of various religious denominations. ${ }^{29}$ In the territory of the former Russian partition, provisions of the cemetery law were included in the provisions of the Administrative Council of the Kingdom of Poland and provisions regarding burying corpses of 31 May 1846 (12 June 1846 according to the Gregorian calendar). ${ }^{30}$

23 Płaza, S., Historia prawa w Polsce na tle porównawczym. Część 3. Okres międzywojenny, Kraków 2001, p. 34.

24 Tunia, A., op. cit., p. 100.

25 Płaza, S., op. cit., p. 33.

26 Ibidem, p. 35.

27 Borecki, P. and Winiarczyk-Kossakowska, M., Prawo pogrzebowe, Warszawa 2013, p. 7.

28 Insadowski, H., op. cit, p. 33.

29 Ibidem, p. 30.

30 Ibidem, pp. 28-29. 
In particular districts, funeral law provisions were, therefore, often not only anachronic, but also differed among themselves, which resulted in many problems with application thereof, especially with regard to the transport of corpses between various district areas. ${ }^{31}$ Problems in applying partition provisions were supposed to be prevented by the especially issued "acts on conflicts of the law": international private law and inter-district private law. ${ }^{32}$ Thus, the basic task of the administration of the young Polish state consisted in the necessary unification of the funeral law in the whole territory of the Second Polish Republic.

The first Polish normative act standardising the contradictory regulations of partition states with regard to the funeral matter was the Act of 17 March 1932 on burying the deceased and declaring the cause of death. ${ }^{33}$ The Act consisted in total of 18 Articles which regulated basic administrative issues related to burial, declaration of the cause of death and administration of cemeteries by referral, in the case of managing Catholic cemeteries, to Article XVII of the Concordat with the Holy See. ${ }^{34}$ At this point, it should be explicitly underlined that the law of the Second Polish Republic was generally characterised with taking into consideration the provisions of the internal law of religious associations in a form of reception thereof or a blanket referral. ${ }^{35}$ It is also important to stress the fact of the personal connection of certain Catholic clergymen with holding high positions in the state denominational administration. ${ }^{36}$

The Act on burying the deceased included specific sanitary provisions regarding the location of cemeteries and the transporting of corpses. Moreover, it imposed on municipalities the obligation to bury corpses "unless nobody else takes this obligation." ${ }^{37}$ With regard to the deceased worshipping in a denomination that does not have its own denominational cemetery, the Act on burying the deceased ensured burial of the corpse at the nearest municipal cemetery in the case of a lack of a proper cemetery in the municipality where the death was declared. ${ }^{38}$ At the

31 Ibidem, p. 35 .

32 Tunia, A., op. cit., p. 102

33 Dz.U. (Journal of Laws) 1932, No. 35, item 359, hereinafter: the Act on burying the deceased.

34 The Concordat between the Holy See and the Republic of Poland signed in Rome on 10 February 1925, Dz.U. (Journal of Laws) 1925, No. 72, item 501.

35 Tunia, A., op. cit., p. 125.

36 The best known example was Rev. Bronisław Żongołłowicz, who was for many years employed as the undersecretary of state at the Ministry of Religious Affairs and Public Education. See: Leszczyński, P., Centralna administracja wyznaniowa II RP. Ministerstwo Wyznań i Oświecenia Publicznego, Warszawa 2006, pp. 246-260.

37 Article $2 \$ 2$ in fine of the Act on burying the deceased.

38 Ibidem, Article $8 \$ 2$ in fine. 
same time, the provisions of the Act obliged "relevant authorities of religious and denominational associations of legal persons" to accept for a specific period of 5 years, corpses of persons not belonging to a given denomination. ${ }^{39}$ It seems that the above provision was aimed at enabling establishing in the meantime municipal cemeteries in Poland that would not be managed by specific religious associations. This task was not completed in the interwar period. Thus, the legal situation related to the burial of suicides continued to exemplify the overwhelming impact of canon law. A significant breakthrough in this issue was brought only by another Act on cemeteries and burying of the deceased of 31 January 1959, passed in the times of the People's Republic of Poland. ${ }^{40}$

The twenty-year interwar period in Poland coincided with the first year of the enforcement of the Code of Canon Law promulgated on 27 May 1917, referred to as the Pio-Benedictine Code. ${ }^{41} \mathrm{CIC} / 1917$ entered into force on 19 May 1918 and thus, as underlined by Rev. Tadeusz Pawluk: "all of the hitherto official collections became invalid." ${ }^{2}$ With reference to the ecclesiastical funeral law provisions, the Code of Canon Law of 1917 decreased the number of persons authorised to be buried inside churches. These changes were to some extent compelled by the growing role of sanitary provisions of the state law initiated at the turn of the $18^{\text {th }}$ and $19^{\text {th }}$ centuries. However, the possibility of burying senior ecclesiastical hierarchs or royal families inside temples was maintained in CIC/1917 to a limited extent. ${ }^{43}$

The Pio-Benedictine Code did not bring significant improvement in the scope of the legal-canon situation of suicides. Worshipers who conscientiously committed a suicide were still deprived of the right to an ecclesiastical funeral. Nonetheless, it is worth noticing the evolution in the approach to suicide. A prominent interwar canonist, Henryk Insadowski, underlined that in order to deprive a worshiper ecclesiastical funeral two crucial premises should be met. The suicide should be "complete" (death only as a result of the suicidal act) and "intentional" (the act intended at committing a suicide).$^{44}$ It is worth mentioning that apart from suicides,

39 Ibidem, Article $15 \$ 1$.

40 Consolidated text: Dz.U. (Journal of Laws) 2019, item 1473; hereinafter: the Act on cemeteries.

41 Codex Iuris Canonici, Pii X Pontificis Maximi iussu digestus, Benedicti Papae XV auctoritate promulgatus, AAS 9 (1917), hereinafter: CIC/1917.

42 It should be underlined that CIC/1917 primarily constituted work providing a codification of canon law. In case of any doubts regarding the interpretation of provisions thereof, priority should have been given to the former canon law. See: Pawluk, T., Prawo kanoniczne według Kodeksu Jana Pawła II. Tom 1. Zagadnienia wstępne i normy ogólne, Olsztyn 2015, pp. 102-103.

43 The code allowed burial in the premises of the Church of, among others: the Pope, cardinals, resident bishops or representatives of royal families; Sobczak, A., op. cit., p. 15.

44 Insadowski, H., op. cit., p. 168. 
CIC/1917 also deprived the deceased of the right to an ecclesiastical funeral as a result of a duel. ${ }^{45}$

The Pio-Benedictine Code did not allow conducting ecclesiastical funerals for numerous categories of worshipers, including persons who were cremated. It took several dozens of years for an in-depth reform of the ecclesiastical funeral law. This came only with the teachings of Vaticanum Secundum.

\section{Evolution of Polish and Canon funeral law in the $2^{\text {nd }}$ half of the $20^{\text {th }}$ century}

The interwar period brought numerous normative changes to the Polish legal system. These, however, had to catch up with the axiological values of the new political reality of Poland after the end of the Second World War. In the first years of the People's Republic of Poland many areas of the law experienced major transformations as compared to the whole twenty-year interwar period. ${ }^{46}$ As aptly stated by Anna Tunia, Soviet law influenced Polish law by way of "infiltration." ${ }^{\text {"I }}$ In the first post-war years, the Act on burying the deceased of 1932 remained in force in the scope of the funeral law. In contrast to many legal acts from the period of the Second Polish Republic it could not be criticised, despite best efforts, for having a "bourgeois-landed" character. Establishing municipal cemeteries and initiating secular funerals formed a crucial novum in the scope of the funeral practice that was basically unknown in the burial culture in the period of the Second Polish Republic. ${ }^{48}$ The need to replace religious funeral ceremonies with secular ceremonies led to the establishment of a profession previously unknown in Poland - a Master of Ceremony. Nonetheless, secular funerals still constituted a substantial minority with regard to confessional ceremonies, despite the state authorities promoting the ideology related to non-religious axiological values.

On 31 January 1959, a new Act on cemeteries was passed, which, in fact, to a large extent copied the hitherto provisions of the Act on burying the deceased of 1932. Article 8 section 3 of the Act on cemeteries of 1959 provided for the right to equal treatment of all with regard to the "set place of burial," which constituted novum with regard to the previously binding provisions. The new Act also guaranteed burial of all deceased in a denominational cemetery, however, on the condition

45 See: Gołąb, J., op. cit, p. 160; Insadowski, H., op. cit., pp. 168-169.

For instance, the matrimonial personal law, which in the interwar period was based solely on district regulations and was unified only in 1945.

47 Tunia, A., op. cit., p. 110.

48 Kubiak, A.E., op. cit., p. 221 ff. 
that there is no municipal cemetery in a given city or town and (initially) only until establishment thereof. ${ }^{49}$ Therefore, with regard to suicides, it was no longer legal to deny burial in a graveyard despite denying the worshipper the ecclesiastical funeral pursuant to CIC/1917.

Nevertheless, only as a result of the amendment to the Act on cemeteries and burying the deceased of 26 June 1997, an unequivocal obligation to bury the deceased "without discrimination" in denominational cemeteries in towns and cities without municipal cemeteries was introduced.$^{50} \mathrm{~A}$ cemetery manager, hence, was no longer authorised to deny burial of a deceased who bought a specific place in a given cemetery. ${ }^{51}$ As aptly underlined by Artur Mezglewski, despite the principle of inviolability of cemeteries guaranteed in the Concordat, ${ }^{52}$ there is no question of excluding Catholic cemeteries "from the jurisdiction of state authorities." 53

It is assumed that the meaning of the so-called right to a grave also covers the right to funeral celebrations. ${ }^{54}$ Therefore, this should be understood as the right to a burial compliant with the beliefs pursuant to the Act of 17 May 1989 on guarantees of the freedom of conscience and religion..$^{55}$ Therefore, the Polish state is a guarantor of the right to a burial. ${ }^{56}$ In the scope of a specific place of burial in a cemetery, in Polish civil law, the so-called right to a grave is distinguished, which is the right of a substantive character, however, only until the deceased's burial in a given place. ${ }^{57}$ In the case of multi-family graves, the right to a specific grave which acquires (together with a burial of the first deceased) the characteristics of a non-substantive right, may constitute a significant source of judicial conflicts pro futuro. ${ }^{58}$

49 Article $8 \$ 2$ of the Act on cemeteries in its original wording.

50 Pietrzak, M., Prawo wyznaniowe, Warszawa 2013, p. 291.

51 Ibidem, pp. 290-291.

52 The Concordat between the Holy See and the Republic of Poland signed in Warsaw on 28 July 1993, Dz.U. (Journal of Laws) 1998, No. 51, item 318.

53 Mezglewski, A., Posiadanie cmentarzy, in: Mezglewski, A. et al., Prawo wyznaniowe, Warszawa 2011, pp. 215-218.

54 Ibidem, p. 217.

55 Consolidated text: Dz.U. (Journal of Laws) 2017, item 1153.

56 Mezglewski, A., op. cit., p. 218.

57 See: Rudnicki, S., Prawo do grobu. Zagadnienia cywilistyczne, Kraków 1999.

58 It is not difficult to imagine litigation concerning violation of personal interests in a form of worshipping the memory of the deceased of a family member of the deceased, when in a given grave other deceased, promoting decidedly different axiological values (including calling to commit suicidal acts), were buried. 
Any discriminatory practices of denominational cemetery managers in the scope of the right to a grave should be considered in the binding legal status as illegal. The illegal discrimination in the scope of the purchased place of burial can result in civil law liability with regard to the relatives of the deceased pursuant to Article 23 and Article 24 of the Civil Code. ${ }^{59}$ It is, in fact, commonly accepted by civil law scholars and commentators and in judicial decisions that the protection of personal interests of the deceased is vested in their relatives. ${ }^{60}$

Illegal disruption of the burial of the deceased who wished to have their secular funeral organised can also constitute possible grounds for prosecuting the denominational cemetery's administrator pursuant to Article 195 section 2 of the Criminal Code. ${ }^{61}$ Unfortunately, incidents infringing the above provisions continue to happen in Poland (e.g. closing the pre-burial house in the cemetery, "refusal" to bury the deceased in the denominational cemetery wrongly identified with the refusal to conduct an ecclesiastical funeral).

Despite explicit indications of the legislator and judicial decisions, there are also cases of illegal secular burials or burials of clergymen outside the premises of cemeteries. ${ }^{62}$

It should be underlined that while the Canon law provisions in the scope of the cemetery law had to be adjusted to the requirements of the Polish law on an on-going basis, the regulations regarding the Catholic funeral remained under the exclusive jurisdiction of the ecclesiastical legislator. The binding Code of Canon Law promulgated by John Paul II no longer includes expressis verbis the ban on conducting a funeral for suicides ${ }^{63}$ however in canon 1184 section 3 of CIC/1983 it refers to the general clause of "manifest sinners." The issue of allocation to a category of the persons deprived of the Catholic funeral occurs in canon provisions of the particular law (e.g. statues of diocesan synods). The general particular law allows conducting an ecclesiastical funeral for a suicide on the condition that they did not promote ostentatiously the idea of suicide during their lifetime. Therefore, the deceased as a result of an assisted suicide and expressing voluntary consent to undergo euthanasia remain deprived of a funeral. It is worth underlining that in the case of a refusal of an ecclesiastical funeral, the issue of possibly causing

59 Consolidated text: Dz.U. (Journal of Laws) 2019, item 1145, as amended.

60 See: Judgement of the Supreme Court of 12 July 1968, I CR 252/68, OSNCP 1970, item 18. See: Bosek, L., Cywilnoprawny status zwłok ludzkich, in: Bosek, L. (ed.), System prawa medycznego. Tom 1. Instytucje prawa medycznego, Warszawa 2018, pp. 603-626.

61 Consolidated text: Dz.U. (Journal of Laws) 2019, item 1950.

62 Judgement of the Supreme Administrative Court of 19 May 1997, SA/Ka 1717/95, LEX No. 31331.

63 Codex Iuris Canonici auctoritate Ioannis Pauli pp. II promulgatus, AAS 75 (1983), entered into force on 27 November 1983. 
outrage among the worshipers in the case of a public nature of the suicide is given a significant importance. ${ }^{64}$ However, contemporary Canon law no longer denies ecclesiastical funerals to persons who were cremated if they did not undergo cremation against Christian notions.

Thus, the thesis on the significant evolution of ecclesiastical funeral law towards liberalisation of the old, strict canons of the previous Code can be assumed.

\section{Conlusion}

The evolution of Polish law and Canon law with regard to the right of suicides in the scope of the right to burial and funeral exemplifies two meaningful phenomena that occurred in two legal systems. On the one hand, the gradually growing role of state legislation is underlined, which only as of the turn of the $18^{\text {th }}$ and $19^{\text {th }}$ centuries started expanding towards regulating the issues regarding the cemetery law that for ages had remained almost the exclusive domain of the internal law of religious associations. On the other hand, the significant evolution of the provisions of the ecclesiastical legislation in the scope of liberalisation of the funeral law of the Catholic Church is invaluable. Not incidentally, apart from suicides (although with significant reservations), the right to the Catholic funeral was also granted pursuant to the modernised Canon law to such categories of the deceased as children dead before baptism or persons who decided to be cremated after death. This indicates the post-Synod changes to the Canon law that were confirmed in the Code of Canon Law promulgated by John Paul II in 1983 that does not include many strict regulations of its predecessor of 1917. Thus, the aforementioned changes should be assessed positively and the hope pro futuro should be expressed that despite the cases of not adhering to the binding legal regulations, they will constitute fundamental standards in practice preventing from funeral, "discrimination" of suicides in Poland.

\section{References}

Bojko, J., Okruszyny z Gremboszowa, Lwów 1911.

Borecki, P. and Winiarczyk-Kossakowska, M., Prawo pogrzebowe, Warszawa 2013.

Bosek, L., Cywilnoprawny status zwłok ludzkich, in: Bosek, L., (ed.), System prawa medycznego. Tom 1. Instytucje prawa medycznego, Warszawa 2018.

64 Janczewski, Z., Ewolucja przepisów dotyczących pogrzebu kościelnego od Kodeksu Prawa Kanonicznego z 1917 roku, "Prawo Kanoniczne" 2000, No. 1-2, pp. 123-140. 
Duma, P., Grób alienata. Pochówki dzieci nieochrzczonych, samobójców i skazańców w późnym średniowieczu i dobie wczesnonowożytnej, Kraków 2010.

Fischer, A., Zwyczaje pogrzebowe ludu polskiego, Lwów 1921.

Gołąb, J., Prawo do pogrzebu i jego wykonanie w prawie kanonicznym i prawie polskim, Rzeszów 2004.

Hołyst, B., Stosunek religii do samobójstwa, in: Hołyst, B., Suicydologia, Warszawa 2012.

Insadowski, H., Kościelne prawo pogrzebowe, Włocławek 1930.

Janczewski, Z., Ewolucja przepisów dotyczących pogrzebów kościelnych od Kodeksu Prawa Kanonicznego z 1917 roku, "Prawo Kanoniczne" 2000, No. 1-2.

Kolbuszewski, J., Cmentarze, Wroclaw 1996.

Kubiak, A.E., Pogrzeby to nasze życie, Warszawa 2009.

Leszczyński, P., Centralna administracja wyznaniowa II RP - Ministerstwo Wyznań Religijnych i Oświecenia Publicznego, Warszawa 2006.

Majer, P., Pogrzeb symboliczny po donacji zwłok na cele naukowe - aspekty prawno kanoniczne, "Annales Canonici” 2016, No. 12.

Mezglewski, A., Posiadanie cmentarzy, in: Mezglewski, A., et al., Prawo wyznaniowe, Warszawa 2011.

Pawluk, T., Prawo kanoniczne według Kodeku Jana Pawła II. Tom 1. Zagadnienia wstępne i normy ogólne, Olsztyn 2015.

Pietrzak, M., Prawo wyznaniowe, Warszawa 2013.

Płaza, S., Historia prawa w Polsce na tle porównawczym. Cz. 3. Okres międzywojenny, Kraków 2001.

Rudnicki, S., Prawo do grobu. Zagadnienia cywilistyczne, Kraków 1999.

Sobczak, A., Poradnik cmentarny. Kościelne i cywilne normy prawne o cmentarzach i chowaniu zmartych, wraz z orzecznictwem, Gniezno 2003.

Tunia, A., Recepcja prawa wewnętrznego związków wyznaniowych w prawie polskim, Lublin 2015.

Walencik, D., Prawo do pogrzebu katolickiego a prawo do pochówku na cmentarzu wyznaniowym, in: Zubert, B.W. and Sztyk, W.J. (eds.), Munus sanctificandi: gaudium vel onus? Zadanie uświęcenia: radość czy ciężar?, Panewniki 2009.

Wrzyszcz, A., Samobójstwo w prawie obowiązujacym na ziemiach polskich do 1932 roku, in: Mozgawa, M. (ed.), Samobójstwo, Warszawa 2017.

\section{CITATION}

KAŹMIERSKI, P., Evolution of the suicides' right to funeral and burial in Canon Law and Polish Law, "Acta Iuris Stetinensis” 2020, No. 1 (Vol. 29), 49-60, DOI: 10.18276/ais.2020.29-04. 